\title{
Aktivitas Penangkal Radikal Hidroksil Fraksi Flavonoid dari Limbah Tongkol Jagung pada Tikus Wistar
}

\author{
Chaleb P. Maanaria*, Edi Suryanto ${ }^{a}$, Julius Pontoh ${ }^{a}$
}

aJurusan Kimia, FMIPA, Unsrat, Manado

$$
\text { KATA KUNCI }
$$

Flavonoid

Radikal hidroksil

Tongkol jagung

\begin{abstract}
A B S T R A K
Penilitian telah dilakukan untuk menentukan kemampuan menangkal radikal hidroksil pada homogenat hati, jantung dan otak tikus wistar dari fraksi flavonoid limbah tongkol jagung. Penelitian dimulai dengan mengekstraksi serbuk tongkol jagung yang sudah dikering anginkan menggunakan cara refluks selama dua jam dengan pelarut etanol $80 \%$. Ekstrak kemudian dipartisi berturut-turut menggunakan petroleum eter, etil asetat, $n$-butanol dan air, selanjutnya ditentukan kandungan total flavonoid serta aktivitas penangkal radikal hidroksil pada homogenat jaringan hati, jantung dan otak tikus wistar. Hasilnya menunjukkan ekstrak etil asetat yang memiliki kandungan total flavonoid yang paling tinggi yaitu 41,926 mg/kg ekstrak, serta kemampuan menangkal radikal hidroksil pada homogenat jaringan hati, jantung dan otak tikus wistar sebesar 90,964\%; 86,875\% dan 68,235\%.
\end{abstract}

KEYW OR D S

Flavonoid

Hydroxyl radical

Corn cob
A B S T R A C T

This research has been conducted to determine radical hydroxyl scavenging ability on a wistar rat tissue homogenate of liver, heart and brain from corn cob waste extract. Research started with with extracting the powder of corn cob which had been air-dried using reflux method during two hours with $80 \%$ ethanol solvent. Then the extract successively partitioned with petroleum ether, ethyl acetate, n-buthanol and water, next determined the flavonoid total content with activities of hydroxyl radical on a wistar rat tissue homogenate. The result showed ethyl acetate extract which has good result for flavonoid total content that is $41,926 \mathrm{mg} / \mathrm{kg}$ extract, with ability of free radical scavenger on a rat tissue homogenate of liver, heart and brain as much as 90,964\%; 86,875\% and 68,235\%.

\section{Pendahuluan \\ Jagung (Zea mays L.) merupakan salah satu jenis tanaman pangan yang sudah lama dikenal dan dibudidayakan di negara-negara berkembang, khususnya di Indonesia. Pemanfaatan biji jagung sebagai sumber pangan dapat menghasilkan tongkol jagung yang pada umumnya dibuang sebagai limbah atau hanya digunakan sebagai pakan ternak dan bahan bakar dapur. Tongkol jagung merupakan bagian terbesar dari buah jagung, sehingga produksi jagung pipilan dalam jumlah yang besar dapat menghasilkan limbah}

tongkol jagung yang cukup banyak. Menurut Direktorat Jenderal Tanaman Pangan (2013), produksi jagung nasional tahun 2013 mencapai 18.510.435 ton, dan dapat diperkirakan jumlah tongkol jagung yang dihasilkan sekitar 13 juta ton.

Jenis radikal bebas yang paling banyak terdapat dalam sistem biologis tubuh adalah radikal yang berasal dari oksigen, dan dikenal sebagai spesies oksigen reaktif (SOR), antara lain anion superoksida $\left(\mathrm{O}_{2}^{-\bullet}\right)$, radikal hidroksil $(\cdot \mathrm{OH})$, radikal alkoksil $\left(\mathrm{RO}^{\bullet}\right)$ dan radikal peroksil (ROO•) (Halliwel dan Gutteridge, 2001). Radikal hidroksil merupakan senyawa radikal yang paling berbahaya karena 
mempunyai tingkat reaktivitas sangat tinggi. Radikal hidroksil dapat merusak tiga jenis senyawa yang penting untuk mempertahankan intregritas sel yaitu, asam lemak tak jenuh, DNA dan protein (Halliwel \& Gutteridge, 2001).

Salah satu senyawa yang dapat menangkal radikal bebas atau bersifat antioksidan ialah senyawa golongan flavonoid, yaitu senyawa polifenol yang terdiri dari 15 atom karbon utama yang tersusun atas dua cincin benzena yang dihubungkan dengan tiga atom karbon yang juga dapat membentuk cincin pyran. Flavonoid memiliki gugusgugus hidroksil $(-\mathrm{OH})$ sehingga dapat menetralkan radikal bebas dengan cara mendonorkan atom hidrogennya sehingga menjadi molekul non radikal yang stabil (Amic dkk., 2003). Contoh dari senyawa flavonoid yang telah diketahui mempunyai aktivitas sebagai antioksidan adalah kuersetin dan katekin. Senyawa golongan flavonoid yang aktif sebagai penangkal radikal bebas kemungkinan besar dapat diperoleh dari limbah jagung yaitu tongkolnya.

Dari beberapa penelitian yang telah dilakukan menyatakan bahwa limbah tongkol jagung mengandung senyawa-senyawa fenolik, flavonoid dan tanin yang mempunyai potensi sebagai antioksidan atau penangkal radikal bebas. Lumempouw dkk. (2012a), Lumempouw dkk. (2012b) dan Saleh dkk. (2012) melaporkan bahwa ekstrak etanol dari tongkol jagung dapat berperan sebagai antioksidan dan tabir surya (anti UV-B). Selain itu, hasil penelitian Wungkana dkk. (2013) menyatakan bahwa fraksi fenolik dari tongkol jagung dapat berperan sebagai penangkal radikal bebas DPPH dan sekaligus sebagai tabir surya. Suryanto dkk. (2013) melaporkan bahwa tongkol jagung mempunyai potensi sebagai penangkal oksigen singlet dan dapat berperan sebagai tabir surya. Oleh karena itu tujuan penelitian ini untuk mengetahui kemampuan menangkal radikal hidroksil dari fraksi flavonoid dalam limbah tongkol jagung pada homogenat jaringan tikus wistar.

\section{Metode}

\subsection{Material penelitian}

Peralatan yang digunakan dalam penelitian ini adalah alat-alat gelas pyrex Iwaki dan Schott Duran, ayakan 2 mes, mikropipet, penggiling, seperangkat alat refluks dan alat evaporator, spatula stainless stell, magnet stirrer, vorteks, desikator, neraca analitik ER-180 A, pompa air Aquila P-1800, vacuum SMAF SXT-1A, oven Mammert, waterbath Thermologic, centrifuge Eba Hettich, spektrofotometer UV-Vis Thermo Scientific Genesys 20.

Sampel tongkol jagung diperoleh dari perkebunan rakyat di kota Tomohon dan jenis jagung yang digunakan ialah jagung manis varietas hibrida. Bahan kimia yang digunakan yaitu, metanol, etanol, etil asetat, $n$-butanol, alumunium klorida, buffer fosfat $\mathrm{pH} 7$, besi(II) sulfat, hidrogen peroksida, asam tiobarbiturat (TBA), asam trikloroasetat (TCA), yang diperoleh dari Merck (Darmstat, Germany). 1,1-difenil-2-pikrilhidrazil (DPPH) diperoleh dari Sigma (St. Louis, USA) serta akuades. Tikus galur wistar sebanyak 2 ekor untuk diambil organ hati.

\subsection{Persiapan, Ekstraksi dan Partisi Sampel}

Sampel tongkol jagung dikeringanginkan sekitar 1 bulan, kemudian dibersihkan dan dipotong kecil-kecil untuk digiling sampai halus setelah itu diayak (2 mes). Sebanyak $150 \mathrm{~g}$ serbuk tongkol jagung diekstraksi dengan cara direfluks menggunakan pelarut etanol 80\% sebanyak 1500 $\mathrm{mL}$, selama 2 jam pada suhu $80-90^{\circ} \mathrm{C}$. Filtrat hasil penyaringan diuapkan dan dikeringkan dalam oven hingga diperoleh ekstrak kental tongkol jagung.

Sebanyak 5 g ekstrak kental dilarutkan dalam $25 \mathrm{~mL}$ akuades. Larutan selanjutnya dipartisi dengan menambahkan $50 \mathrm{~mL}$ petroleum eter, dikocok dalam labu pemisah dan didiamkan selama 10-15 menit hingga terdapat dua lapisan (akuades pada lapisan bawah dan petroleum eter pada lapisan atas). Kedua lapisan yang terbentuk kemudian dipisahkan. Proses penambahan petroleum eter pada lapisan bawah (akuades) yang sudah dipisahkan diulangi dua kali. Lapisan atas (petroleum eter) yang terbentuk selama tiga kali partisi digabungkan dan disebut sebagai ekstrak partisi petroleum eter (EPPE).

Lapisan akuades sisa dari proses partisi petroleum eter kemudian dipartisi lebih lanjut dengan etil asetat dan dilanjutkan dengan $n$ butanol. Proses yang terjadi sama dengan proses partisi dengan pelarut petroleum eter. Lapisan etil asetat yang nantinya akan terbentuk selama tiga kali partisi digabungkan dan disebut ekstrak partisi etil asetat (EPEA), begitu pula dengan lapisan $n$ butanol yang disebut ekstrak partisi $n$-butanol (EPB) dan sisa lapisan akuades disebut sebagai ekstrak partisi akuades (EPA). Hasil partisi yaitu EPPE, EPEA, EPB, dan EPA diuapkan pelarutnya dan dikeringkan dalam oven hingga diperoleh ekstrak kering, kemudian ekstrak EPA dilarutkan dalam etanol dan disebut ekstrak partisi etanol (EPE) lalu dikeringkan. Setiap ekstrak dihitung rendemennya menggunakan rumus berikut:

$$
\% \text { rendemen }=\frac{\text { berat ekstrak }(g)}{\text { berat serbuk }(g)} \times 100 \%
$$

\subsection{Penentuan Kandungan Total Flavonoid}

Kandungan total flavonoid ekstrak tongkol jagung ditentukan menurut metode Meda $d k k$. (2005). Sebanyak $2 \mathrm{~mL}$ larutan ekstrak $1 \mathrm{mg} / \mathrm{mL}$ dimasukan dalam tabung reaksi lalu ditambah dengan $2 \mathrm{~mL} \mathrm{AICl}_{3} 2 \%$ yang telah dilarutkan dalam etanol, kemudian divorteks. Absorbansi ekstrak dibaca pada spektrofotometer visibel dengan panjang gelombang $415 \mathrm{~nm}$. Kandungan total flavonoid dinyatakan sebagai $\mathrm{mg}$ ekivalen kuesertin/kg ekstrak. 


\subsection{Uji Aktivitas Penangkal Radikal Hidroksil dalam Homogenat Jaringan Tikus Galur Wistar}

Penentuan ini menggunakan metode Lai $d k k$. (2001). Hati, jantung dan otak dari tikus digiling dan ditimbang, hati $0,15 \mathrm{~g}$, jantung $0,4 \mathrm{~g}$ dan otak $0,5 \mathrm{~g}$. Selanjutnya masing-masing organ dilarutkan dengan larutan buffer fosfat $\mathrm{pH} 7$ sebanyak $10 \mathrm{~mL}$, divorteks selama 15 menit kemudian disentrifugasi 3000 rpm selama 10 menit dan diambil supernatannya.

Setelah pembuatan homogenat selesai, dipipet $0,5 \mathrm{~mL}$ supernatan (hati, jantung dan otak) dimasukkan ke dalam tabung reaksi, kemudian ditambahkan $0,05 \mathrm{~mL}$ buffer fosfat $\mathrm{pH} 7,0,03 \mathrm{~mL}$ $\mathrm{FeSO}_{4} 5 \mathrm{mM}, 0,03 \mathrm{~mL} \mathrm{H} \mathrm{O}_{2}$ 0,3\% dan 0,05 mL ekstrak $1 \mathrm{mg} / \mathrm{mL}$. Selanjutnya campuran divorteks dan diinkubasi pada suhu ruang selama 10 menit dan siap diuji dengan metode TBA (Thiobarbituric Acid).

Uji menggunakan metode TBA dilakukan dengan cara $0,5 \mathrm{~g}$ larutan ditambahkan dengan 4 $\mathrm{mL}$ TCA $10 \%$ divorteks kemudian disentsrifugasi $3000 \mathrm{rpm}$ selama 10 menit lalu diambil supernatannya. Supernatan dimasukkan kedalam tabung reaksi dan ditambahkan 2,5 mL TBA 0,02 M lalu divorteks dan dipanaskan dalam waterbath dengan suhu $100^{\circ} \mathrm{C}$ selama 10 menit. Didinginkan dan dibaca absorbansinya pada panjang gelombang $532 \mathrm{~nm}$ dengan menggunakan spektrofotometer visibel dan dihitung persentase penghambatan radikal hidroksil $(\cdot \mathrm{OH})$ dengan persamaan:

Aktivitas penangkal radikal $\cdot \mathrm{OH}(\%)=$

$$
\left[1-\frac{\text { absorbansi sampel }}{\text { absorbansi kontrol }}\right] \times 100 \%
$$

\section{Hasil dan Pembahasan}

\subsection{Ekstraksi dan Partisi}

Proses refluks $600 \mathrm{~g}$ serbuk tongkol jagung manis yang berwarna putih krem dengan menggunakan pelarut $6 \mathrm{~L}$ etanol $80 \%$ selama 2 jam menghasilkan ekstrak berbentuk pasta sebanyak $28,810 \mathrm{~g}$ dengan warna coklat tua, sehingga menghasilkan rendemen sebesar $4,802 \%$. Pemilihan metode ekstraksi dengan cara refluks dan pelarut etanol $80 \%$ berdasarkan penelitian sebelumnya yaitu penelitian Wungkana dkk. (2013) dan Lumempouw dkk. (2012a).

Ekstraksi adalah suatu proses pemisahan dua atau lebih komponen yang diinginkan dengan menambahkan suatu pelarut untuk melarutkan komponen tersebut, prinsip ekstraksi pelarut yaitu berdasarkan kelarutan komponen tersebut dalam pelarut yang digunakan (Suryanto, 2012). Salah satu metode ekstraksi adalah refluks, yaitu metode ekstraksi komponen dengan cara mendidihkan campuran antara sampel dan pelarut yang sesuai pada suhu dan waktu tertentu, serta uap yang terbentuk dapat diembunkan dalam kondensor agar kembali ke labu.

Pelarut yang digunakan adalah pelarut yang bersifat polar yaitu etanol, hampir semua produk metabolit sekunder dapat larut dalam etanol, khususnya untuk senyawa-senyawa yang banyak mengandung gugus hidroksil $(-\mathrm{OH})$ dan yang bersifat polar. Menurut Shahidi \& Naczk (1995) penambahan co-solvent seperti air dapat membantu dalam mengekstraksi semua golongan senyawa polifenol dari dalam jaringan tumbuhan. Pemanasan pada proses refluks dapat membantu menghancurkan membran-membran sel dari sampel, sehingga pelarut dapat lebih mudah masuk ke dalam sel untuk proses pengekstrakan (Miller, 1975). Senyawa-senyawa metabolit sekunder disintesis di dalam sel, untuk flavonoid disintesis melalui jalur fenilpropanoid yang diaktivasi oleh kompleks multienzim sitosol, yang dikenal sebagai flavonoid metabolon yang terhubung pada retikulum endoplasma pada permukaan sitoplasma (Stafford, 1974).

Rendemen ekstrak yang didapat dari proses partisi $15 \mathrm{~g}$ ekstrak awal tongkol jagung manis dengan menggunakan pelarut petroleum eter, etil asetat, $n$-butanol, akuades dan etanol dapat dilinat dalam Tabel 1.

Tabel 1. Rendemen ekstrak partisi petroleum eter (EPPE), ekstrak partisi etil aseatat (EPEA), ekstrak partisi $n$-butanol (EPB), ekstrak partisi akuades (EPA) dan ekstrak partisi etanol (EPE).

\begin{tabular}{|c|c|c|}
\hline Ekstrak & Massa (g) & Rendemen (\%) \\
\hline EPPE & 2,323 & 15,487 \\
\hline EPEA & 3,081 & 20,540 \\
\hline EPB & 2,124 & 14,160 \\
\hline EPA & 7,351 & 49,007 \\
\hline EPE & - & - \\
\hline
\end{tabular}

Partisi yang dilakukan menggunakan pelarut yang berdasarkan tingkat kepolarannya, untuk pelarut petroleum eter yaitu pelarut yang non polar digunakan untuk mengekstrak senyawa-senyawa non polar seperti minyak, karotenoid, streroid dan triterpenoid. Sedangkan untuk pelarut semipolar seperti etil asetat dan $n$-butanol menurut Markham (1988) dapat mengekstrak senyawa flavonoid aglikon, sedangkan flavonoid glikosida dan glikosida lainnya lebih mudah larut dalam air. Rendemen yang tinggi dari ekstrak air disebabkan karena adanya senyawa glikosida atau gula yang strukturnya kompleks dengan berat molekul yang tinggi. EPA tidak larut dalam etanol sehingga ekstrak EPE tidak diperoleh.

\subsection{Kandungan Total Flavonoid Ekstrak Hasil Partisi}

Kandungan total flavonoid yang dinyatakan sebagai mg kuersetin/kg ekstrak dari ekstrak partisi petroleum eter (EPPE), etil asetat (EPEA), $n$-butanol (EPB) dan akuades (EPA) hasil partisi ekstrak awal tongkol jagung dengan konsentrasi $1 \mathrm{mg} / \mathrm{mL}$ dapat dilihat pada Gambar 1. 


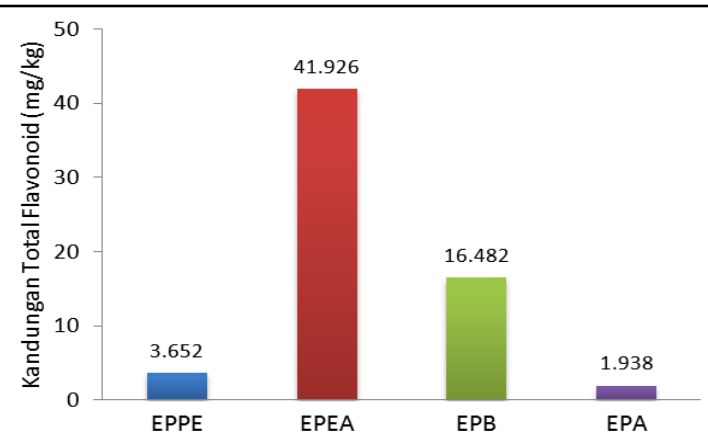

Gambar 1. Diagram kandungan total flavonoid dari ekstrak partisi petroleum eter (EPPE), ekstrak partisi etil asetat (EPEA), ekstrak partisi $n$-butanol (EPB) dan ekstrak partisi akuades (EPA).

Senyawa flavonoid dapat membentuk kompleks dengan logam $\mathrm{Al}^{3+}$ yaitu pada gugus hidroksi (cincin A) dan keton (cincin C) yang bertetangga dan pada orto-dihidroksi (cincin B) yang dapat menghasilkan warna kuning. Semakin kuat intensitas warna kuning yang terbentuk menunjukkan kandungan flavonoid dalam ekstrak tersebut semakin banyak (Meda dkk., 2005; Markham, 1988).

Berdasarkan Gambar 1, kandungan total flavonoid dari EPEA adalah yang paling tinggi dibanding ekstrak yang lain. Menurut Markham (1988) dan Grotewold (2006) flavonoid aglikon seperti isoflavon, flavanon dan flavon serta flavonol yang termetoksilasi cenderung lebih larut dalam pelarut yang semi polar seperti eter, kloroform, etil asetat dan $n$-butanol, sedangkan flavonoid glikosida lebih larut dalam pelarut yang lebih polar seperti air. Adanya gugus eter (R-O-R) dan gugus keton $\left(\mathrm{R}_{2} \mathrm{C}=0\right)$ pada struktur flavonoid yang menyebabkan menurunnya polaritas flavonoid. Untuk pelarut petroleum eter yang bersifat non polar tidak terlalu efektif untuk melarutkan flavonoid. Jadi dari hasil ini dapat menunjukkan bahwa dalam ekstrak etil asetat banyak mengandung senyawa flavonoid aglikon atau flavonoid yang tidak terikat dengan gula.

\subsection{Aktivitas Penangkal Radikal Hidroksil dalam Homogenat Jaringan Tikus Galur Wistar dari Ekstrak Hasil Partisi}

Aktivitas penangkal radikal hidroksil pada homogenat hati, jantung dan otak dari ekstrak partisi petroleum eter (EPPE), etil asetat (EPEA), $n$ butanol (EPB) dan akuades (EPA) hasil partisi ekstrak awal tongkol jagung dengan konsentrasi 1 $\mathrm{mg} / \mathrm{mL}$ dapat dilihat pada Gambar 2.

Radikal hidroksil dapat terbentuk dalam sistem biologis dari hidrogen peroksida $\left(\mathrm{H}_{2} \mathrm{O}_{2}\right)$ yang bereaksi dengan ion logam besi $\left(\mathrm{Fe}^{2+}\right)$ yang disebut reaksi Fenton, $\mathrm{H}_{2} \mathrm{O}_{2}+\mathrm{Fe}^{2+} \rightarrow \mathrm{Fe}^{3+}+\cdot \mathrm{OH}+\cdot \mathrm{OH}$. Selain itu, radikal hidroksil juga dapat dihasilkan dari reaksi antara hidrogen peroksida anion superoksida $\left(\mathrm{O}_{2}{ }^{\circ-}\right)$ dengan katalis ion logam besi yang dikenal dengan reaksi Haber-Weiss, $\mathrm{H}_{2} \mathrm{O}_{2}+$ $\mathrm{O}_{2}{ }^{-} \rightarrow \cdot \mathrm{OH}+{ }^{-} \mathrm{OH}+\mathrm{O}_{2}$ (Halliwel \& Gutteridge, 1992).

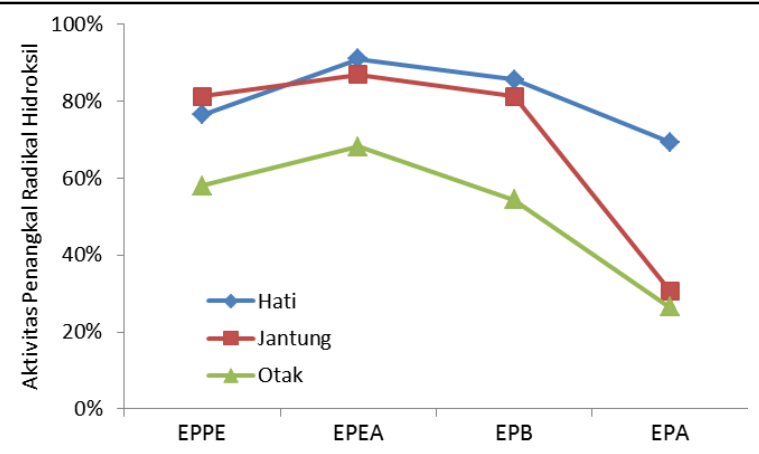

Gambar 2. Grafik aktivitas penangkal radikal hidroksil dari dari ekstrak partisi petroleum eter (EPPE), ekstrak partisi etil asetat (EPEA), ekstrak partisi $n$ butanol (EPB) dan ekstrak partisi akuades (EPA).

Malondialdehida (MDA) adalah senyawa dialdehida $\left(\mathrm{C}_{3} \mathrm{H}_{4} \mathrm{O}_{2}\right)$ yang merupakan produk akhir peroksidasi lipid akibat adanya spesies oksigen reaktif $(S O R)$ di dalam tubuh. Peningkatan radikal bebas dalam tubuh, seperti $\mathrm{OH}^{\cdot}$ akan menyerang asam lemak tak jenuh ganda yang merupakan penyusun membran sel, melalui pembentukan radikal karbon, radikal peroksil dan peroksidasi lipid. Sebagai akibatnya rantai PUFA yang semula panjang, akan terputus menjadi senyawa-senyawa sederhana seperti hidrokarbon (pentana, etana) dan aldehida seperti malondialdehida (MDA) (Pribadi \& Ernawati, 2010). MDA merupakan salah satu produk dari proses peroksidasi lipid yang bersifat toksik dan karsinogen yang dapat menyebabkan makrofag dalam sel (Madhavi dkk., 1996).

Pengukuran MDA banyak dilakukan sebagai indeks tidak langsung dari kerusakan oksidatif yang disebabkan oleh peroksidasi lipid. Prinsip pengukuran MDA adalah reaksi satu molekul MDA dengan dua molekul asam tiobarbiturat (TBA) membentuk kompleks senyawa MDA-TBA yang berwarna merah muda dan dapat dibaca dengan spektrofotometer UVVis pada $\lambda 532 \mathrm{~nm}$ (Ozben, 1997).

Dilihat dari grafik pada Gambar 2, EPEA memiliki kemampuan menangkal radikal hidroksil pada homogenat hati, jantung dan otak yang lebih baik dari ekstrak-ekstrak yang lain yaitu sebesar 90,964\%; 86,875\% dan 68,235\%, hal ini sejalan dengan kandungan total flavonoid dari EPEA yang juga lebih tinggi dibanding ekstrak-ekstrak yang lain. Artinya senyawa-senyawa flavonoid dalam tongkol jagung dapat bertindak sebagai antioksidan primer yang dapat menangkal radikal hidroksil sehingga dapat melindungi organ-organ vital seperti hati, jantung dan otak. Selain itu, EPPE dan EPB juga mempunyai potensi sebagai penangkal radikal hidroksil. Senyawa antioksidan seperti flavonoid dapat mendonorkan atom hidrogen kepada radikal hidroksil yang reaktif dan menghasilkan air, $\mathrm{AH}+$ $\cdot \mathrm{OH} \rightarrow \mathrm{A}^{\cdot}+\mathrm{H}_{2} \mathrm{O}$ (Ali dkk., 2013).

Dalam metode ini juga dapat dilihat kemampuan senyawa flavonoid dalam EPEA sebagai 
pengkelat ion logam besi. Menurut Winarsi (2007), beberapa logam atau mineral di dalam tubuh manusia seperti besi dapat bertindak sebagai katalis atau inisiator dalam terbentuknya radikal, salah satunya adalah mengkatalis hidrogen peroksida menjadi radikal hidroksil. Brown $d k k$. (1998) menyatakan bahwa senyawa flavonoid dapat berinteraksi dengan ion logam besi dan tembaga dengan membentuk kelat. Posisi o-dihidroksi dan adanya gugus hidroksi dan keton yang bertetangga dapat membentuk kompleks dengan beberapa logam menurut Markham (1988), sehingga dapat mencegah terbentuknya radikal bebas dan peroksidasi lipid yang dapat menghasilkan MDA.

\section{Kesimpulan}

Dari hasil penelitian menunjukkan bahwa faksi flavonoid dalam ekstrak partisi etil asetat dari limbah tongkol jagung mempunyai kemampuan sebagai penangkal radikal hidroksil pada homogenat jaringan hati, jantung dan otak tikus wistar yang lebih baik dibanding dengan ekstrak partisi petroleum eter, $n$-butanol dan akuades.

\section{Daftar Pustaka}

Ali, H.M., A. Abo-Shady, H.A.S. Eldeen, H.A. Soror, W.G. Shousha, O.A. Abdel-Barry, \& A.M. Saleh. 2013. Structural Features, Kinetics and SAR Study of Radical Scavenging and Antioxidant Activities of Phenolic and Anilinic Compounds. Chemistry Central Journal. 7: 1-9.

Amic, D., D. Beslo, N. Trinajstic, \& Davidovic. 2003. Structure-Radical Scavenging Activity Relationship of Flavonoids. Croatia Chemica Acta. 76: 55-61.

Brown, J.E., H. Khodr, R.C. Hider, \& C. Rice-Evans. 1998. Structural Dependence of Flavonoid Interactions with $\mathrm{Cu}^{2+}$ Ions: Implication for Their Antioxidant Properties. Biochemical Journal. 330: 1173-1178.

Burda, S., \& W. Oleszek. 2001. Antioxidant and Antiradical Activities of Flavonoids. Journal of Agricultural and Food Chemistry. 49: 2774-2779.

Conde, E.F., M.C.Cadahia, Garcia-Vallejo, B.F.D. Simon, \& J.R.G. Adrados. 1997. Low Molecular Weight Polyphenol in Cork of Quercus Suber. Journal of Agricultural and Food Chemistry. 45: 2695-2700.

Direktorat Jenderal Tanaman Pangan. 2013. Usaha Tani: Statistik Pertanian. Menteri Pertanian Republik Indonesia

Grotewold, E. 2006. The Science of Flavonoids. Springer, New York.

Halliwel, B., \& J.M.C. Gutteridge. 1992. Biologically Relevant Metal Ion-Dependent Hydroxyl Radical Generation An Update. FEBS Letter. 307: 108-112.

Halliwel, B., \& J.M.C. Gutteridge. 2001. Free Radicals in Biology and Medicine. Oxford University Press, New York.

Julkenen-Titto, R. 1985. Phenolic Constituents in the Leaves of Northern Willows: Methods for the
Analysis of Certain Phenolic. Journal of Agricultural and Food Chemistry. 33: 213-217.

Lai. LS., ST. Chou, \& WW. Chau. 2001. Studies on the Antioxidative Activities of Hsian-tsao (Mesona procumberns Hemsl) Leaf Gum. Journal of Agricultural and Food Chemistry. 49: 963-968.

Lumempouw, L.I., E. Suryanto, \& J.E. Paendong. 2012b. Aktivitas Anti UV-B Ekstrak Fenolik Dari Tongkol Jagung (Zea mays L.). JURNAL MIPA UNSRAT ONLINE. 1: 1-4.

Lumempouw, L.I., J.E. Paendong, L.I. Momuat, \& E. Suryanto. 2012a. Potensi Antioksidan dari Ekstrak Etanol Tongkol Jagung (Zea mays L.). Chemistry Proggres. 5: 49-56.

Madhavi, D.L., S.S. Desphande, \& D.K. Salunkhe. 1996. Food Antioxidants: Technological, Toxicologocal and Health Perspectives. Marcel Dekker, New York.

Markham, K.R. 1988. Cara Mengidentifikasi Flavonoida. Terjemahan Padmawinata, K. ITB Press, Bandung.

Meda, A., C.E. Lamien, M. Romito, J. Milliogo, \& O.G. Nacoulina. 2005. Determination of the Total Phenolic, Flavonoid and Proline Content in Burkina Fasan Honey, as well as Their Radical Scavenging Activity. Journal of Food Chemistry. 91: 571-577.

Miller, J.M. 1975. Separation Methods in Chemical Analytics. John Wiley Publisher, New York.

Molyneux, P. 2004. The Use of the Stable Free Radical Diphenylpicrylhidrazyl (DPPH) for Estimating Antioxidant Activity. Songklanakarin Journal of Science and Technology. 26: 211-219.

Ozben, T. 1997. Free Radicals, Oxidative Stress and Antioxidants: Pathological and Physiological Significance. NATO ASI, Antalya.

Pribadi, F.W., \& D.A. Ernawati. 2010. Efek Cathecin Kadar Asam Urat, C-Reaktive Protein (CRP) dan Malondialdehid Darah Tikus Putih (Rattus novergicus) Hiperurisemia. Mandala of Health. 4: 39-46.

Saleh, L.P., E. Suryanto, \& A. Yudistira. 2012. Aktivitas Antioksidan Dari Ekstrak Tongkol Jagung (Zea mays L.). PHARMACON. 1: 20-24.

Shahidi, F., \& M. Naczk. 1995. Food Phenolics: Sources, Chemistry, Effects and Application. Technomic Publishing Co. Inc., Lancaster-Basel.

Stafford, H.A. 1974. Possible Multienzyme Complexes Regulating the Formation of C6-C3 Phenolic Compounds and Lignins in Higher Plants. Recent Advances in Phytochemistry. 8: 53-79.

Suryanto, E. 2012. Fitokimia Antioksidan. Putra Media Nusantara, Surabaya.

Suryanto, E., L.I. Momuat, A. Yudistira, \& F. Wehantouw. 2013. The Evaluation of Singlet Oxygen Quenching and Sunscreen Activity of Corncob Extract. Indonesian Journal of Pharmacy. 24: 269-278.

Winarsi, H. 2007. Antioksidan Alami dan Radikal Bebas. Kanisius, Yogyakarta.

Wungkana, I., E. Suryanto, \& L. Momuat. Aktivitas Antioksidan dan Tabir Surya Fraksi Fenolik dari Limbah Tongkol Jagung (Zea mays L.). PHARMACON. 2: 149-155. 